\title{
Study on Prohibitions of Ancient Chinese Costumes in Black Series
}

\author{
Xiaomeng $\mathrm{Qu}^{1}$ \\ ${ }^{1}$ Fashion, Art Design Institute, Donghua University, Shanghai, China \\ Correspondence: Xiaomeng Qu, Fashion, Art Design Institute, Donghua University, Room 201, No. 42, Lane \\ 5366, Hu Min Road of Minhang District, Shanghai 201199, China. Tel: 86-21-5415-4812. E-mail: \\ shelley1118@foxmail.com
}

\author{
Received: July 13, 2013 Accepted: August 30, 2013 Online Published: October 29, 2013 \\ doi:10.5539/ass.v9n15p272 URL: http://dx.doi.org/ass.v9n15p272
}

\begin{abstract}
China is a historical country with extensive and profound civilization, in which the Chinese Costume has always been a brilliant feature. Black series occupies an important position in the color institution of ancient Chinese Costumes. The prohibition on black series costumes also has a significant meaning in ancient China. By discussing prohibitions related to black series in ancient Chinese costume institution, this paper studied two typical colors used by people of different classes as their clothes which are pure black and dark black. Meanwhile, it also discussed evolution and characteristics of costumes prohibitions in black series at different historical periods of ancient China through the research on the historical records and relics.
\end{abstract}

Keywords: ancient China, costumes, color, black, prohibitions of costumes

China has a byword: "People first discovered color in the distance and then observed patterns after coming close." Human visual system is especially sensitive to color. To this conclusion, color is very important in basic visual attribute of objects. Correspondingly, in people's cognition sequence for objects, color occupies an important position. The above theory can also be applied to our cognition for costumes. We all know that a piece of clothing contains many elements, such as color, pattern and material, and color can be regarded as the most effective way to improve the identification of the clothes.

In ancient China, people often adopted different colors to decorate their appearances, and such consciousness almost appeared at the same time when people started wearing clothes. The earliest application of color was based on the psychological measurement of people's aesthetic view and primitive decoration willingness. For instance, in the Neolithic Age, archaeological remains of Shandingdong Site presented the elaborate ornaments like animal teeth and stone beads on the dead body as well as red hematite powder around the bone fossils. After a period of time, such aesthetic consciousness changed. Especially since the class society, costumes color had been endowed with specific symbolic meanings. Social members in different classes were required to wear clothes with different colors, and rules were set for costumes color of emperors and imperial members, civil and military officials at different levels, and civilians. In formal occasions, such provisions were especially strict. Such requirements had been brought into costume institution gradually and become provisions that people must observe. If the provisions were violated, people would be punished. Therefore, prohibitions of costumes colors occurred in ancient China.

The color of ancient Chinese costumes has been a hot topic discussed across the spectrum in academia. Many scholars have launched their research on this topic. Some of them discussed the ancient Chinese costumes in color from the angle of enculturation, such as The dress color in Tang and Song dynasties which comparison on Tang and Song in dress color changes. Some focused on the Chinese nation's unique color philosophy, such as $A$ Study of Five-color Aesthetics in Chinese Traditional Clothing and On the Color Folk during Song and Yuan Dynasty in China. The researchers suggested that the social politics, economics and science affected the color folk changed. While there were also some scholars studied on the topic from the viewpoint of technology by analysing the existing archaeological information and paintings such as Dunhuang Dyestuff and the Breaking of the Purple Clothing System in the Tang and Song Dynasties Focusing on P.3644 in the French Collection of Dunghuang Documents. The research above all mentioned about the ancient Chinese clothing in color and also included the black series, but they haven't go on system expound upon the theme as a complex evolutionary process. 
The author once wrote a paper named Study on Prohibitions of the Purple Costumes in Ancient China to talk about prohibitions of costumes colors by taking purple as an example, which had mentioned that dyeing and weaving technology for ancient Chinese costumes has provided technical support for diversity of ancient Chinese costumes colors. The article also introduced that ancient Chinese costumes included "Sacred color" and "Secondary color" according to the traditional theory of the Yinyang-wuxing-Earth, Metal, Wood, Fire then Water Purple is a typical example of category in prohibitions of costumes colors, and its status has developed from the humble "secondary color" to color that represents higher social class. In the theory of the five elements, red, yellow, blue, white and black are the five primary colors. Black was regarded as the national color of the Qin Dynasty. The black robes were used as sacrifice garment and the formal dress of the literary intelligentsia. Except the prohibitions of costumes in purple series, black series is also a representative category in prohibitions of ancient Chinese costumes colors. This paper focused on the details from prohibitions of costumes in black series and their evolution and characteristics at different historical periods by analysing the Chinese ancient literary works, such as ancient novels, notes and Twenty-for histories which are important classical works on China's history.

\section{Color Classification of Black Series in Ancient China}

A classical book of ancient China named Say civil solution word described black as "the color of the heavy smoke caused by fire." Black gives people a plain, solemn and serious visual impression. The author collected a lot of historical documents related to Chinese ancient costumes and founded that in prohibitions of ancient Chinese costumes colors, the parts related to black series mainly focused on two typical colors which are pure black named "Zao" and dark black named "Xuan".

The interpretation about pure black in Shi Ming said "Before the sun rises, everything is black in dark" Later the word "Zao" was created and one of its paraphrases as a noun is Zaodou that is a black vegetable dye with a long history in China. According to the records, Zaodou is the fruit on oak in August and September, and "its shell can be used for dyeing". When Zao is treated as an adjective, it means the black color dyed with Zaodou.

The other one of black series related to prohibitions of black costumes is Xuan (dark black). Among vocabularies of "black" family, "Xuan" symbolized a high level in the social society. The symbolic meaning of "Xuan" had been explained in many famous ancient Chinese books. For instant, Zhouyi (The Book of Changes) states that in ancient China, "The dark black color symbols the sky and the yellow color symbols the earth." Say civil solution word records that, "The color named Xuan means deep and remote. It contains both black and red colors." Zhouyi Zhu Shu points out, "Xuan (dark black) can be gained by adding black ink into the black and red dye for several times." Therefore, it can be inferred that Xuan (dark black) is achieved through dip dyeing of red dye for several times. In Ting Qin Tu (Beijing's Palace Museum collection), Emperor Huizong of Song Dynasty is supposed to wear a dark black robe as his townwear.

\section{Prohibitions of Pure Black Costumes}

Pure black is common in ancient Chinese costumes colors. In the Han Dynasties, pure black clothes could be used by different social classes. It records that Guanzhong, a famous philosopher and politician said," Civilians are not allowed to wear colorful clothes." Civilians often adopted "white" and "black" as their costume colors in Han Dynasty. In the early years of the Han Dynasty, the rulers also wore pure black clothes in order to show their diligent and thrifty. Han Shu - Biographies of Jia Yi describes Emperor Wen of Han Dynasty like this, "Emperor Wen of Han wears plain and black sackcloth, while rich people use silk to decorate their walls." According to the existing archaeological information such as the paintings, most officials in Han Dynasty wore pure black clothes. Han Shu - Biographies of Xiao Wangzhi recorded that the Caoital Official, Chang Zhang, had been worn pure black clothes for more than 20 years. Ruchun Du explained, "Though there are different official robes in different seasons, officials have to wear pure black clothes when presented themselves before the emperor."

In Sui Dynasty, the costume institution provided that "butchers and merchants from the bottom of society have to wear black clothes" recorded in Suishu. In early Tang Dynasty, inheriting the institution in Sui Dynasty, pure black clothes were still for civilians with lower ranks. It is worth mentioning specially that pure black clothes were used as the uniform for ordinary soldiers gradually in early Tang Dynasty, but at that time, officials not of military status and civilians were not prohibited to wear pure black clothes. In case of this, civilians and soldiers wore clothes with similar colors. In order to avoid confusion, in the 2nd year of Guangde (764 AD), Emperor Daizong of Tang prohibited "officials not of military status and civilians to wear black robes" so as to make the army clothing stand out. However, civilians still wore pure black clothes, although being banned repeatedly. Hong Chen, a writer in Tang Dynasty wrote Dongcheng Laofu Zhuan, which reflected the social phenomenon. It said that in Kaiyuan (about 713-741 AD), when an old man goes out with his cane and stands in the middle of 
the road, he can hardly find any people who wear white clothes. The pure black clothes were very popular and dew to this it seemed that "all the people are soldiers". In the 1st year of Kaicheng (836 AD), Emperor Wenzong of Tang emphasized again that "many people wear pure black jackets and try to pretend to be soldiers", and such phenomenon should be strictly forbidden. It's worth noting that except civilians who wore pure black clothes and made it hard to distinguish themselves from soldiers, officials also acted like this and caused disorder among them. According to the previous prohibition that officials not of military status are forbidden to wear pure black robes, we can infer that wearing pure black clothes was not only popular among civilians, but also prevailed in officials. Dang Wang of Song Dynasty said in Tang Yu Lin that, "Black costumes were popular in late Tang Dynasty, and the colors included purple green and dark black. When the war happened, both soldiers and civilians wore pure black clothes, and this was considered to be an ominous sign."

In Song Dynasty, more stringent prohibitions were made in terms of the situation for officials wearing pure black clothes. In the previous Dynasty, both officials and civilians were prohibited to wear black clothes, but in the Northern Song Dynasty, common people were allowed to wear pure black costumes. It is recorded in Song $S h i \cdot Y u F u$ Zhi that in the 7th year of Taiping Xingguo during Emperor Song Taizong's decades in power (982 AD), Fang Li, scholar of the Imperial Academy, presented to the emperor, "According to previous law, civilians had to wear white clothes. Now I suggest that outpost officers, provincial graduates and civilians be allowed to wear pure black clothes." Moreover, it was provided that officials "can wear purple black and white robes as their housecoat for informal situations". Shortly after, in the 2nd year of Duangong (989 AD), "servants in yamun, common people, merchants, vaudevillians, and actors or actresses not within formal compilation should only wear pure black and white clothes". Obviously, pure black clothes were treated as the costumes for people with lower social statuses. Tales of the Old Capital · Yingxin states, "In Song Dynasty, well-known prostitutes possessed many black clothes and gold \& silver jewellery." Shunmin Zhang a famous literati in Song Dynasty wrote a book named Hua Man $\mathrm{Lu}$, in which he mentioned that his brother was accused of wearing pure black robes. Because such behavior was not fitting of his scholar's role. On that account, to stand out from the common people, in the 3rd year of Jingde (1006 AD), Emperor Zhenzong of Song commanded that "officials should never wear pure black clothes when coming in and out of the royal court. Anybody who disobeys the law will be punished".

\section{Prohibitions of Dark Black Costumes}

As mentioned above, dark black symboled a high level in the social society, and was adopted by the emperor as the color of his townwear. Prohibitions of costumes in dark black color are typical in Ming Dynasty. Tiangong Kaiwu (Exploitation of the Works of Nature) says, "Dark black can be gained by dyeing indigo into dark green and boiling calamite and bayberry bark together. Another way is to soak blue bud with water and then add in iron vitriol."

Taizu of Ming adopted dark black and yellow to emblem the sky and the earth after studying ancient laws and rites, so dark black was listed as the monopoly costumes color of royal household and it was forbidden among civilians. Taizu of Ming issued an imperial decree that strictly prohibited officials and civilians to use dark black during the years of Hongwu (1368-1398 AD) for several times, and offenders together with the dyeing and weaving craftsmen would be punished. In the 14th and 15th years of Hongwu (1381 and 1382 AD), Taizu of Ming issued an imperial decree to strictly forbid government officials, soldiers and civilians to wear dark black, yellow and purple costumes. Ming Hui Dian describes "The emperor's costume in sacrificial occasions should be dark black and yellow" in the 16th of Hongwu (1383 AD); in the 24th year of Hongwu (1391 AD), it was provided that "government officials can't wear clothes in black, yellow and purple colors and embroidered with dragon and phoenix patterns. Offenders together with the dyeing or weaving people will be punished." Shizong of Ming also attached great importance to control the extension of wearing dark black clothes. In the 8th year of Jiajing (1529 AD), in terms of the emperor's clothes, "the upper garment should be dark black and the lower garment should be yellow". The purpose of establishing the costumes institution of adopting dark upper garment and yellow lower garment is to emphasize ancient laws and rites. It is recorded in Ming Shi $\cdot Y u F u$ Zhi that in the 8th year of Jiajing, the emperor told the Cabinet Minister, Cong Zhang, "I asked the Weaving and Dyeing Bureau to investigate crowns and costumes at early times, and the dark black and yellow colors were adopted before to symbolize the sky and the earth."

In Ming Dynasty, foreign envoys were especially forbidden to buy and sell dark black, yellow, purple and pure black silk fabrics, "After foreigners from different places pay tributes and get their rewards, they are allowed to carry out transactions in the courier station for 3 to 5 days. It's forbidden to purchase historical books, yellow, purple and black silk fabrics, and other forbidden objects." 
In paintings of royal court in Ming Dynasty, Xing Le Tu is an event painting to record the life scenes of the emperor and such paintings often have high real degree. In these paintings, the emperor often wears dark black robes. For instance, Xing Le Tu of Xuande Emperor now stored in the Palace Museum was drawn by Xi Shang who was a famous court painter in Ming Dynasty, and this painting reflects the scene in which the emperor of Ming Dynasty goes on a tour. In the pictures, Xuande Emperor appeared to be dressed in dark black robes for several times.

\section{Conclusion}

Taking the discussion above into consideration, we can come to conclusion as follows:

Black is widely used in Chinese ancient costumes. The past research on this topic mostly focused on the general concept of black clothes and few studies have touched upon segmentations of the black color.

Prohibitions on dressing in black are the basis of study of Chinese ancient costumes in black series, because they can reflect the life custom in different historical periods. By sorting-out and researching ancient books and existing archaeological information about the prohibitions, the author found that in ancient Chinese costume institution, prohibitions of costumes in black series mainly center on "Zao" (pure black) and "Xuan" (dark black).

The findings showed that black color used in Chinese ancient costumes can be divided into different types according to different dyeing technique. As mentioned above, there are mainly two typical black colors in Chinese ancient costumes which are Pure Black and Dark Black. Pure black named "Zao" can be obtained by refining from the oak shell, while the dark one named "Xuan" can be gained by dyeing indigo into dark green and boiling calamite and bayberry bark together.

Through the inductive analysis of the costumes prohibitions in black series, it shows that the color of the clothes embodies the class idea of supremacy of the imperial power and the aesthetic consciousness in the history. In ancient China, pure black (Zao) costumes were often applied to the people with low-level social status. Prohibitions of pure black costumes are to distinguish the civilians from officials. In contrast, dark black (Xuan), especially in the Ming Dynasty, was a traditional Chinese symbol of royalty. The use rights of dark black clothes were monopolised by the emperor. Prohibitions of dark black costumes mainly highlighted the image of exclusivity in order to keep the emperors in power.

\section{References}

Ban, G. (1999). The History of the Former Han Dynasty. Beijing: Zhonghua Book Company.

Dong, H. (1983). Entire Donovan. Beijing: Zhonghua Book Company.

Liang, K. J. (1990). Song Yuan local chronicles series. Beijing: Zhonghua Book Company.

Liu, X. (1996). Guan Zhong. Gui Yang: Guizhou people's Publishing House.

Liu, Z. C., \& Zhao, Y. P. (2010, September). Dunhuang Dyestuff and the Breaking of the Purple Clothing System in the Tang and Song Dynasties Focusing on P.3644 in the French Collection of Dunghuang Documents. Journal of Nanjing Normal University, 5.

Qu, X. M. (2012). Study on Prohibitions of the Purple Costumes in Ancient China. Asian Social Science, 8(8). http://dx.doi.org/10.5539/ass.v8n8p134

Shen, S. X. (1995). Code of Great Ming Dynasty. Shanghai: Shanghai Ancient Books Publishing House.

Tuo, T. (2000). History of Song Dynasty. Beijing: Zhonghua Book Company.

Wang, B. (1995). Tang Huiyao. Beijing: Zhonghua Book Company.

Wang, B. (1998). The book of changes. Beijing: Zhonghua Book Company.

Wang, D. (1987). Tang Yu Lin. Beijing: Zhonghua Book Company.

Wu, X. P. (2009, October). A Study of Five-color Aesthetics in Chinese Traditional Clothing. Journal of Ningbo University(Education Edit), 31(5).

Xu, S. (2002). Analytical Dictionary of Chinese Characters. Beijing:Zhonghua Book Company.

Xu, S. (2002). Analytical Dictionary of Chinese Characters. Beijing: Zhonghua Book Company,.

Yang, J. W. (2005, December). On the Color Folk during Song and Yuan Dynasty in China. Yinshan Academic Journal, 18(6).

Zhang, T. Y. (2000). History of Ming Dynasty. Beijing: Zhonghua Book Company.

Zheng, X. (1999). Zhou Shu. Beijing: Peking University Press.

Zhou, M. (2007). Tales of the Old Capital. Beijing: Zhonghua Book Company.

Zhu, Y. (2010). The dress color in Tang and Song dynasties. Dissertation of master degree of Shaanxi Normal University. 


\section{Appendix}

The List of the Prohibitions on the Costumes in Black Series

Time Identity Content

Tang Dynasty

Emperor Zhenzong of Song ordered that the eunuch with lower priority should never wear pure black clothes when coming in and out of the royal court. Offenders will be punished.

Officials and Emperor Renzong of Song ordered that the officials and common people who lived in the capital should not wear clothes with white pattern-on-black and brown background.

Emperor Renzong of Song ordered that the officials and common people should not wear black clothes.
The 2nd year of Guangde

(764 AD)

Song Dynasty

The 3rd year of Jingde

(1006 AD)

Officials Common people

Officials and

Common people

Officials and

Common

Ming Dynasty

The 24th year of Hongwu (1391

AD)

The 2nd year

of Tianshun

(1458 AD)

The 17 th year

of Tianshun

(1504 AD)
Officials

Foreign

envoys

Officials

Taizu of Ming ordered that clothes of government officials and curtains cannot be in black, yellow and purple colors and embroidered with dragon and phoenix patterns. Offenders together with the craftsman who is in charge of dyeing or weaving work will be punished.

Chengzu of Ming Dynasty prohibited foreign envoys to buy and sell dark black, yellow, purple and pure black silk fabric.

Yingzong of Ming Dynasty ordered that officials cannot wear clothes with the patterns of dragon, lion, Baoxiang flower and the color of dark black, yellow, purple.

Xiaozong of Ming Dynasty ordered that the eunuchs Eunuchs especially with lower status cannot wear clothes in dark black, yellow and purples.

\section{Copyrights}

Copyright for this article is retained by the author(s), with first publication rights granted to the journal.

This is an open-access article distributed under the terms and conditions of the Creative Commons Attribution license (http://creativecommons.org/licenses/by/3.0/). 